\title{
ASSESSING THE PROGRESS OF INDIA TOWARDS SUSTAINABLE DEVELOPMENT GOALS BY 2030
}

\author{
Radhika Bhanja ${ }^{1}$ and Koel Roychowdhury ${ }^{2}$ \\ ${ }^{1}$ Research Scholar, ${ }^{2}$ Assistant Professor, \\ Department of Geography, Presidency University, Kolkata (West Bengal) India \\ Email: koel.geog@presiuniv.ac.in.radhika.rs@presiuniv.ac.in
}

\begin{abstract}
The United Nations has taken an important decision to go forward with pursuing sustainable development by introducing the 2030 Global Agenda in 2015. The Sustainable Development Goals (SDGs) are universal policy agenda to envisage a world free of poverty, hunger, disease and violence, where all forms of life can thrive and promises to build a safe, resilient and sustainable world. To assess the performance of India in achieving sustainability by 2030, the study aims to understand how far India is from achieving SDGs at both the national and subnational level. In this study, the present status of India's primary targets of SDGs is analyzed with the help of a composite index. A cluster analysis was also performed to examine the region-specific and issue-specific problems of sustainable development in India. At the subnational level, 14 out of 29 states have performed well in the composite index. This study has identified the arenas India needs to focus on to achieve sustainability by 2030.
\end{abstract}

Key words: SDG, Cluster Analysis, Region-Specific Problem, Issue-Specific Problems

\section{Introduction}

The concept of sustainability dates back many centuries. However, with the recent global awareness of the fact that the impact of human interventions on nature is out-weighing its renewal process, this idea has been incorporated in the global political agenda (Leal Filho et al., 2018). So much so, that the United Nations in 2015 proposed a set of 17 goals with 169 targets popularly known as the Sustainable Development Goals (SDGs) to be achieved by 2030 by all its member states. Prior to this, the Millennium Development Goals (MDGs) were incorporated between 2000 and 2015. MDGs consist of eight goals to reduce poverty, and child mortality, HIV/AIDS and other diseases, improve maternal health, promote education, gender equality and to conserve the environment, and promote global partnership among nations. The MDGs were structured to achieve positive trajectories of social and economic development by initiating an international consensus among both rich and poor countries to improve the lives of the poorest people in the world (Fukuda-Parr, 2004). Although many countries have achieved remarkable progress in some indicators of MDGs, the progress is very uneven among different countries and population groups. The SDGs, also known as the 2030 Agenda, on the other hand, primarily aims to deliver more importance to the provision of food and water, inequality in the distribution and allocation of resources, environmental problems and importance of policy implementation as a means to achieve sustainability more effectively than the MDGs (Pradhan, Costa, Rybski, Lucht, \& Kropp, 2017).

In order to help policy-makers address various challenges of governing and implementing the SDGs in a systematic manner, it is necessary to focus on the interactions between different goals of SDGs. Concerns regarding proper monitoring and evaluation of the progress of each SDG have surfaced (Lu, Nakicenovic, Visbeck, \& Stevance, 2015; Reyers, Stafford-Smith, Erb, Scholes, \& Selomane, 2017). The poor performance of many East and South Asian countries in the SDG Index and Dashboard global report 2017 highlights their 
failure to provide adequate basic infrastructure, equality and environmental sustainability to its population. In order to overcome these challenges, it has been recommended to device practical metrics such as establishing monitoring mechanisms, choosing standards to evaluate progress of each target and goal, increase infrastructure capacity to track progress in human dimensions and societal changes and finally to standardize the data for all nations to become verifiable at high-level political forums (Allen, Metternicht, \& Wiedmann, 2018)

According to the SDG Index and Dashboard global report 2017, India ranked 110 and 116 out of 157 nations in 2016 and 2017 respectively, behind Nepal, Sri Lanka, Bhutan and China. Like many other developing countries, India's role to promote sustainable development has been overshadowed by the unavailability of basic infrastructure (Rao, 2015), rising food insecurity (Vani et al., 2017) and degrading environment quality (Gurjar, Ravindra, \& Nagpure, 2016). Panda \& Mohanty (2018) have computed the required rate of progress for selected health indicators of SDGs throughout 2005 to 2015 and developed a composite index of health to study how India at a sub-national level has progressed in providing health related amenities and infrastructure to its population. It was observed that if India can maintain this rate of progress, then achieving the maternal health target of SDG is possible by 2030, but achieving the nutrition and other health targets by 2030 will be difficult. At a sub-national level, Kwatra et al. (2016) have combined social, economic and environmental sustainability index to formulate a Sustainable Development Index of India and have concluded that better performance of sustainable development is visible in states with higher economic sustainability. There exist rural-urban inequalities at both state and district level in the allocation of sustainable access to water and sanitation infrastructure (Chaudhuri \& Roy, 2017). Although India's performance in providing access to improved water is achieved at a national level, the condition needs inspection at its lower administration level, especially in rural areas. A national level time series map of land use-land cover change in India at a decadal interval of 1985, 1995 and 2005 have noted a decrease of around 34881 sq. km of forest cover (Roy et al., 2015). Maharashtra and Madhya Pradesh, parts of north east India and Cauvery river basin have witnessed the maximum conversion of forest cover to agricultural land. However, the increase in mangrove forest was noticed from 1995-2005, which can be attributed to the imposition of strict coastal legislation programmes initiated by the Government of India.

\section{Objectives}

To ascertain whether India will be able to achieve SDGs by 2030 , it is necessary to visualize the role of the nation in attaining the primary targets of different sustainable development goals at both national and sub-national level. Overall development in the social, economic and environmental sectors requires an inclusive planning strategy, designed around the needs of the primary stakeholders of the country that will benefit both the present and the future generations. The objectives of the research are as follows:

1. To assess the performance of India, at state level, in the primary indicators of sustainable development and simultaneously analyses the development trends of these indicators.

2. To identify region-specific and issue-specific challenges affecting India at both national and sub-national level.

\section{Datasets}

In order to identify the policies implemented at both national and subnational levels to reduce disparity and bring about overall development, variables defining the primary targets of the previously mentioned SDGs were considered and depicted in table 1. Data were obtained for 2011 from Census of India, Central Statistical Office, Ministry of Environment, Forest and Climate Change, National Crime Records Bureau and National Family Health Survey 2015-16. In this study, only nine indicators were selected to assess the progress of India towards 
sustainable development because it not only involves creation of indices to analyse the achievement in the basic level of development but also takes an attempt to project the issues that can limit the progress of India from achieving these indicators by 2030 .

\section{Method}

\section{Composite Index}

The indicators representing the primary targets of SDG were selected and aggregated to assess their performance at state level. In order to calculate the SDG Index, Sachs et al. (2016) used the data available for at least 80 percent of the 149 UN Member States with a national population greater than 1 million. Same methodology was used to calculate the PSDG index of Indian states. Some of the indicators rejected the normality hypothesis at 5 percent significance level, therefore rescaling of the data was done from 0 to 100 using minimum-maximum method for each indicator, where 0 denoted worst performance and 100 denoted the best performance, given by the formula;

$$
X_{\text {new }}=\left(\left(X_{i}-X_{\min }\right) /\left(X_{\max }-X_{\min }\right)\right)^{*} 100
$$

where, $X_{\text {new }}$ is the normalized value of the indicator,

$X_{i}$ is the original value of the indicator,

$X_{\min }$ and $X_{\max }$ are the minimum and maximum value of the indicator from the total observations.

Table 01: Selected Indicators to Study Performance of India in Primary Targets of SDGs

\begin{tabular}{|c|c|c|c|c|}
\hline \multicolumn{2}{|r|}{ Goal } & \multirow{2}{*}{\begin{tabular}{|l|}
\multicolumn{1}{|c|}{ Primary Target } \\
By 2030, end hunger and ensure access by all people, \\
in particular the poor and people in vulnerable \\
situations, including infants, to safe, nutritious and \\
sufficient food all year round
\end{tabular}} & \multirow{2}{*}{$\begin{array}{l}\text { Indicator } \\
\text { ce of } \\
\text { arishment (in } \\
\text { ge) }\end{array}$} & \multirow{2}{*}{\begin{tabular}{|l|}
\multicolumn{1}{|c|}{ Source } \\
National Family \\
Health Survey
\end{tabular}} \\
\hline 2 & $\begin{array}{l}\text { End hunger, achieve food security and } \\
\text { improved nutrition and promote sustainable } \\
\text { agriculture }\end{array}$ & & & \\
\hline 3 & $\begin{array}{l}\text { Ensure healthy lives and promote well-being } \\
\text { for all at all ages }\end{array}$ & $\begin{array}{l}\text { By } 2030 \text {, reduce the global maternal mortality ratio to } \\
\text { less than } 70 \text { per } 100,000 \text { live births }\end{array}$ & $\begin{array}{l}\text { Maternal mortality ratio } \\
\text { (modeled estimate, per } \\
100,000 \text { live births) }\end{array}$ & $\begin{array}{l}\text { National Family } \\
\text { Health Survey }\end{array}$ \\
\hline \multirow[b]{2}{*}{6} & \multirow{2}{*}{$\begin{array}{l}\text { Ensure availability and sustainable } \\
\text { management of water and sanitation for all }\end{array}$} & $\begin{array}{l}\text { By } 2030 \text {, achieve universal and equitable access to } \\
\text { safe and affordable drinking water for all }\end{array}$ & $\begin{array}{l}\text { Improved water source } \\
\text { (percentage of population } \\
\text { with access) }\end{array}$ & Census Reports \\
\hline & & $\begin{array}{l}\text { By } 2030 \text {, achieve access to adequate and equitable } \\
\text { sanitation and hygiene for all and end open defecation, } \\
\text { paying special attention to the needs of women and } \\
\text { girls and those in vulnerable situations }\end{array}$ & $\begin{array}{l}\text { Improved sanitation facilities } \\
\text { (percentage of population } \\
\text { with access) }\end{array}$ & Census Reports \\
\hline 7 & $\begin{array}{l}\text { Ensure access to affordable, reliable, } \\
\text { sustainable and modern energy for all }\end{array}$ & $\begin{array}{l}\text { By } 2030 \text {, ensure universal access to affordable, reliable } \\
\text { and modern energy services }\end{array}$ & $\begin{array}{l}\text { Proportion of population } \\
\text { with access to electricity } \\
\text { (percentage of population) }\end{array}$ & Census Reports \\
\hline 8 & $\begin{array}{l}\text { Promote sustained, inclusive and sustainable } \\
\text { economic growth, full and productive } \\
\text { employment and decent work for all }\end{array}$ & $\begin{array}{l}\text { Achieve higher levels of economic productivity through } \\
\text { diversification, technological upgrading and innovation, } \\
\text { including through a focus on high-value added and } \\
\text { labour-intensive sectors }\end{array}$ & $\begin{array}{l}\text { Annual growth rate of real } \\
\text { GDP per employed person } \\
\text { (constant } 2011 \text { PPP \$) }\end{array}$ & $\begin{array}{l}\text { Central Statistical } \\
\text { Office }\end{array}$ \\
\hline 9 & $\begin{array}{l}\text { Make cities and human settlements inclusive, } \\
\text { safe, resilient and sustainable }\end{array}$ & $\begin{array}{l}\text { Proportion of urban population living in slums, informal } \\
\text { settlements or inadequate housing }\end{array}$ & $\begin{array}{l}\text { Population living in slums ( } \% \\
\text { of urban population) }\end{array}$ & Census Reports \\
\hline 15 & $\begin{array}{l}\text { Protect, restore and promote sustainable use } \\
\text { of terrestrial ecosystems, sustainably manage } \\
\text { forests, combat desertification, and halt and } \\
\text { reverse land degradation and halt biodiversity } \\
\text { loss }\end{array}$ & $\begin{array}{l}\text { By } 2020 \text {, ensure the conservation, restoration and } \\
\text { sustainable use of terrestrial and inland freshwater } \\
\text { ecosystems and their services, in particular forests, } \\
\text { wetlands, mountains and drylands, in line with } \\
\text { obligations under international agreements }\end{array}$ & $\begin{array}{l}\text { Forest area as a proportion } \\
\text { of total land area (\% of land } \\
\text { area) }\end{array}$ & $\begin{array}{l}\text { Ministry of } \\
\text { Environment, } \\
\text { Forest and } \\
\text { Climate Change }\end{array}$ \\
\hline 16 & $\begin{array}{l}\text { Promote peaceful and inclusive societies for } \\
\text { sustainable development, provide access to } \\
\text { justice for all and build effective, accountable } \\
\text { and inclusive institutions at all levels }\end{array}$ & $\begin{array}{l}\text { Significantly reduce all forms of violence and related } \\
\text { death rates everywhere }\end{array}$ & $\begin{array}{l}\text { Number of victims of } \\
\text { intentional homicide per } \\
100,000 \text { population }\end{array}$ & $\begin{array}{l}\text { National Crime } \\
\text { Records Bureau }\end{array}$ \\
\hline
\end{tabular}

Source: (United Nations, 2016)

In this study equal weightage was given to all the indicators to derive the composite SDG index. Thresholding of the data for upper boundary was followed using the method provided by Sachs et al., (2016). The threshold value which was already mentioned in the targets of SDGs was set as the upper boundary of the targets for rescaling. Some targets did not mention any threshold condition, for them, the average values of the top five best performances of the indicators were chosen as the threshold for upper boundary. Sachs et al. (2016) had considered arithmetic mean and geometric mean to aggregate the SDG scores. However, both yielded similar results with a correlation coefficient of 0.977 and very similar 
rankings. To calculate the Primary Sustainable Development Goal Index (PSDG) for India, the methodology used is as follows: the indicators were normalized using the minimum-maximum method. The upper boundary was set at 100 percent for indicators measured in percentage. An equal weightage was given to all the indicators and an arithmetic mean was used for aggregating their scores.

\section{Cluster Analysis}

A cluster analysis was done to examine the possibility of spatial clustering of different states of India on the basis of their pattern of achieving the basic goals of sustainable development. To hierarchically arrange the indicators according to their progress in India at a sub-national level, the same method was applied to segregate the indicators according to their rate of achievement in different states of India. Many application of cluster analysis for country level assessment with respect to global indicators have been reported (Hirschberg, Maasoumi, \& Slottje, 1991; SaintArnaud \& Bernard, 2003; Omorou et al., 2016; Sulkowski \& White, 2016; Kwon, Lee, \& Lee, 2018). This method classifies cases into groups that are relatively homogeneous within themselves and heterogeneous between each other, on the basis of a defined set of variables. The identified groups are called clusters.

In the current study, first, hierarchical clustering was performed to classify cases into homogeneous groups and then from the explored number of clusters, a non-hierarchical $k$ means clustering was used to classify the states into the clusters of similar performance (Fraley \& Raftery, 1998). Hierarchical clustering is an agglomerative process that iterates $n$ times starting from $n$ clusters to a single cluster and in this process, it stores the coefficients of the distance between each iteration (Sarstedt \& Mooi, 2014). To group the cases that are alike, the distance measures are small and similarity measures are large. The variables selected are continuous in nature but have different units and therefore, standardization of data was conducted using the minimum-maximum method to scale the numeric variables in the range of 0 and 100. The upper and lower boundaries for standardization was selected using the rescaling methodology for calculating the composite index provided by Sachs et al. (2016). In this study, the minimum-maximum method used for cluster separation provided the best results with respect to near spacing and distance spacing and therefore, this method was used for standardization (Milligan \& Cooper, 1988). In hierarchical clustering, Ward's method combined with squared Euclidean distance interval measure for clustering the similar observations was used.

\section{RESULTS AND DISCUSSION}

\section{India's Performance at the Sub-National Level}

Although at the national level, India seemed to have performed fairly well in some indicators, a detailed study at the sub-national level revealed that many of the states are lagging far behind the targets in those indicators of sustainable development goals. The indicators of access safe drinking water facility and intentional homicide that seem to be achieved at the national level are only partially achieved at the sub-national level. The indicators that are in transition for India have performed moderately at the sub-national level. The indicators of undernourishment and maternal mortality rate have performed poorly for the majority of the states. In India, 194.6 million people were undernourished in the year 2014-2016 (FAO, 2016). Five out of 29 states having the least development in this sector are Uttar Pradesh (23.2 percent), Chhattisgarh (26.10 percent), Bihar (29.20 percent), Jharkhand (29.60 percent) and Madhya Pradesh (30.20 percent). Maternal mortality ratio of India, as a whole, was 181 per 100,000 populations in 2014 . However, at the state level, this was 328 for Assam, 292 for Uttarakhand and Uttar Pradesh while 235 for both Rajasthan and Odisha. On the other hand, for indicators that are in transition phase such as access to electricity, it was noted that for states such as Goa, Himachal Pradesh 
and Punjab, 95 percent of the households have access to electricity compared to Bihar, UP, Assam, Odisha and Jharkhand where more than half of its population do not have access to the same. The urban slum population, which is in transition for India at national level, seems to be on track at its sub-national level.

The indicators that are lagging behind for India at the national level have also performed poorly at the sub-national level. The percentages of households with access to improved sanitation facilities in rural areas have increased from 21.92 percent in 2001 to 30.7 percent in 2011, while for urban areas the percentage had increased from 73.72 percent in 2001 to 81.4 percent in 2011. An overall increase of 10 percent is witnessed in the percentages of household with access to improved sanitation facility in India from 2001 to 2011. The economic growth of India is not limited to GDP growth rate, investment, income inequality, demographic changes and productivity of workforce of the country. Maharashtra earns the highest Gross State Domestic Product, followed by Tamil Nadu and Uttar Pradesh. The data also highlights that Uttar Pradesh though earns higher than 27 states of India, yet it lacks to fulfill the basic infrastructural needs of the population living there. Forests form an integral part in maintaining harmony between the ecological environment, economically viable and socially just forest communities. Forest areas are found in abundance in the states of North-east India, mainly Mizoram, Arunachal Pradesh, Nagaland, Meghalaya and Manipur. Apart from that, the percentages of forest areas are less than 50 percent in 23 states and less than 15 percent in 7 states of West and North India. Table 2 shows a comparison of the performance of India at both national and sub-national level on the selected indicators of SDGs, while figure 2 shows the PSDG Index score of all the states of India.

\section{Table 02: Comparison of the Performance of India in the PSDG Index at Both National and Sub-National Level}

\begin{tabular}{|l|l|}
\hline Indicators & \multicolumn{1}{|c|}{ Performance at the State Level } \\
\hline $\begin{array}{l}\text { Access to an improved } \\
\text { water source }\end{array}$ & Only 34 percent of the states are on track \\
\hline Intentional homicide & Only 5 out of 29 states are lagging behind to reduce homicide rates \\
\hline Undernourishment & Lagging for most states \\
\hline Maternal mortality ratio & $\begin{array}{l}\text { On an average about 19.5 percent of the population of all the states } \\
\text { is undernourished. }\end{array}$ \\
\hline Access to electricity & $\begin{array}{l}60 \text { percent of the states can provide } 75 \text { percent of its population } \\
\text { with access to electricity }\end{array}$ \\
\hline Urban slum population & $\begin{array}{l}\text { The state with the highest percentage of urban slum population is } \\
\text { Maharashtra with only } 12 \text { percent of its population living in slums }\end{array}$ \\
\hline $\begin{array}{l}\text { Access to improved } \\
\text { sanitation facilities }\end{array}$ & All the states have performed poorly, except Kerala and Mizoram \\
\hline $\begin{array}{l}\text { GDP per employed } \\
\text { person }\end{array}$ & $\begin{array}{l}40 \text { percent of the total number of states need to provide more } \\
\text { employment opportunities to its population }\end{array}$ \\
\hline Forest area & $\begin{array}{l}\text { Most of the states have lower forest cover. Only } 5 \text { out of 29 states } \\
\text { have 75 percent of their land covered with forest }\end{array}$ \\
\hline
\end{tabular}

Source: Author's calculation

\section{Identification of patterns of hindrances in the development}

The study uses cluster analysis to identify the region-specific problems and issue-specific problems hindering the development of India at its sub-national level. The states were grouped into homogeneous cases that exhibit the same socio-economic and environmental development progress. Therefore, from the hierarchical cluster analysis, five clusters were identified. Figure 1a represents the performance of Indian states in PSDG Index and figure $1 \mathrm{~b}$ presents a visual representation of the states that have been clubbed together according to their performance of India in the PSDG Index at a sub-national level. 


\section{Region-specific Hindrances}

The variations in achieving sustainable development of India are reflected at the sub-national level, when the indicators of development, which were studied for India as a whole, were measured for different states of India. The states were first, grouped based on the similar levels of achievement in PSDG index with the help of cluster analysis (as shown in figure 1b) and then the effectiveness and implementation progress of the developmental policies of each states belonging to different groups were examined. From the cluster analysis, it was observed that 11 out of 29 states that belonged to Group 1 experience higher levels of achievement in indicators of access to improved water and electricity. The states of Karnataka, Maharashtra, Uttarakhand and West Bengal have lower rates of undernourishment than the neighbouring states. The performance of the states belonging to Group 1 show varied results for labour productivity. Although the states of Andhra Pradesh, West Bengal and Karnataka show low progress in GDP per employed population, their share in employment in major sectors of agriculture, manufacturing and service sectors together are more than 6 percent each while Delhi, the leading state in the economic indicator of GDP per employed population, has contributed to only 3.62 percent of India's total employed population in the above mentioned sectors. These states have very little forest cover and wetlands (Reserve Bank of India, 2018). These states need to introduce strong environment protection acts to manage their natural resources.

The North East states, which mainly belong to Group 2 have very poor access to safe and improved drinking water facility and therefore a total of Rs. 842.50 crore was released by Ministry of Water and Sanitation under NRDWP (Ministry of Drinking Water and Sanitation, 2013). In the following year, NRDWP had targeted to fully recover 4104 rural households and partially recover 5826 rural households from a total of 118189 rural households, which are suffering from poor water quality status. Out of this target, 2521 fully and 5030 partially affected rural habitations were achieved. The 2017 Electricity Statistics reports that only 1 percent of installed generation capacity of electricity is concentrated in northeast India while the western region accounts for the highest share (36 percent), followed by northern region (26 percent), southern region (24 percent) and eastern region (13 percent). The states have huge potential for drawing hydropower and therefore, efforts have been initiated to develop its energy, generating potential into reality (Mahanta, 2010). These states, apart from Kerala, are also facing major challenges in developing their economy. Their agriculture productivity has declined, their share from the manufacturing sector in the GDP is negligible, unstable law and order in few of the northeast states, restrictions on the issue of trade licenses and ownership of land has led to a development setback in these northeast states.

The states belonging to group 3 are interestingly very small in terms of their area, but they are very densely populated. Group 3 has performed the best in all the indicators of sustainable development except the ones belonging to environmental conservation and management. Delhi, being the capital of India has witnessed massive rate of urbanization and economic growth in India and simultaneously it has been able to provide its population with basic amenities, employment opportunities and world-class infrastructure of health and education, but has extensively compromised on its environmental aspects. Sikkim, on the other hand, is very rural, yet because of its low population, it is self-sufficient. Goa, a small coastal state in western India, is more urban than rural and its performance in achieving primary goals of sustainable development is excellent. These states have almost achieved the basic goals of sustainability and should concentrate on the other goals and targets of the 2030 Agenda.

The states belonging to group 4 and 5 have performed the worst in all the indicators of the PSDG index. The composite scores for these states, as shown in figure 1a, are very low. The states have the lowest rate of access to basic amenities, the worst performance in Human 
Development Index (Mukherjee \& Chakraborty, 2014), and a poor economy. Over the years, many government initiatives have been introduced to improve their conditions. To encourage positive outcomes from rural sanitation programmes few states have converged Nirmal Bharat Abhiyan and Mahatma Gandhi National Rural Employment Guarantee Scheme. According to the Annual Report 2013-14 of Ministry of Drinking Water and Sanitation, the states of Haryana, West Bengal, Karnataka, Maharashtra, Andhra Pradesh, Jharkhand, Bihar and Madhya Pradesh have converged these two programmes and are trying to develop more toilet in schools and Anganwadi to provide a safe and hygienic environment in schools. The percentage of population living below poverty line in India was 21.9 percent in 2011-2012 and the states with percentage greater than that of national average belonged to Bihar and Uttar Pradesh from Group D and Madhya Pradesh, Assam, Orissa, Jharkhand and Chhattisgarh from Group E (Planning Commission, 2014). Undernourishment among children between 0-60 months is very critical in India and the states of Bihar, Uttar Pradesh, along with Madhya Pradesh, Jharkhand, Meghalaya, Chhattisgarh and Gujarat have a greater percentage of children suffering from undernourishment than the national average.

Figure 01: (a) PSDG Index Score of all the states of India; (b) Clustering of Indian States into different groups according to their performance in the PSDG Index

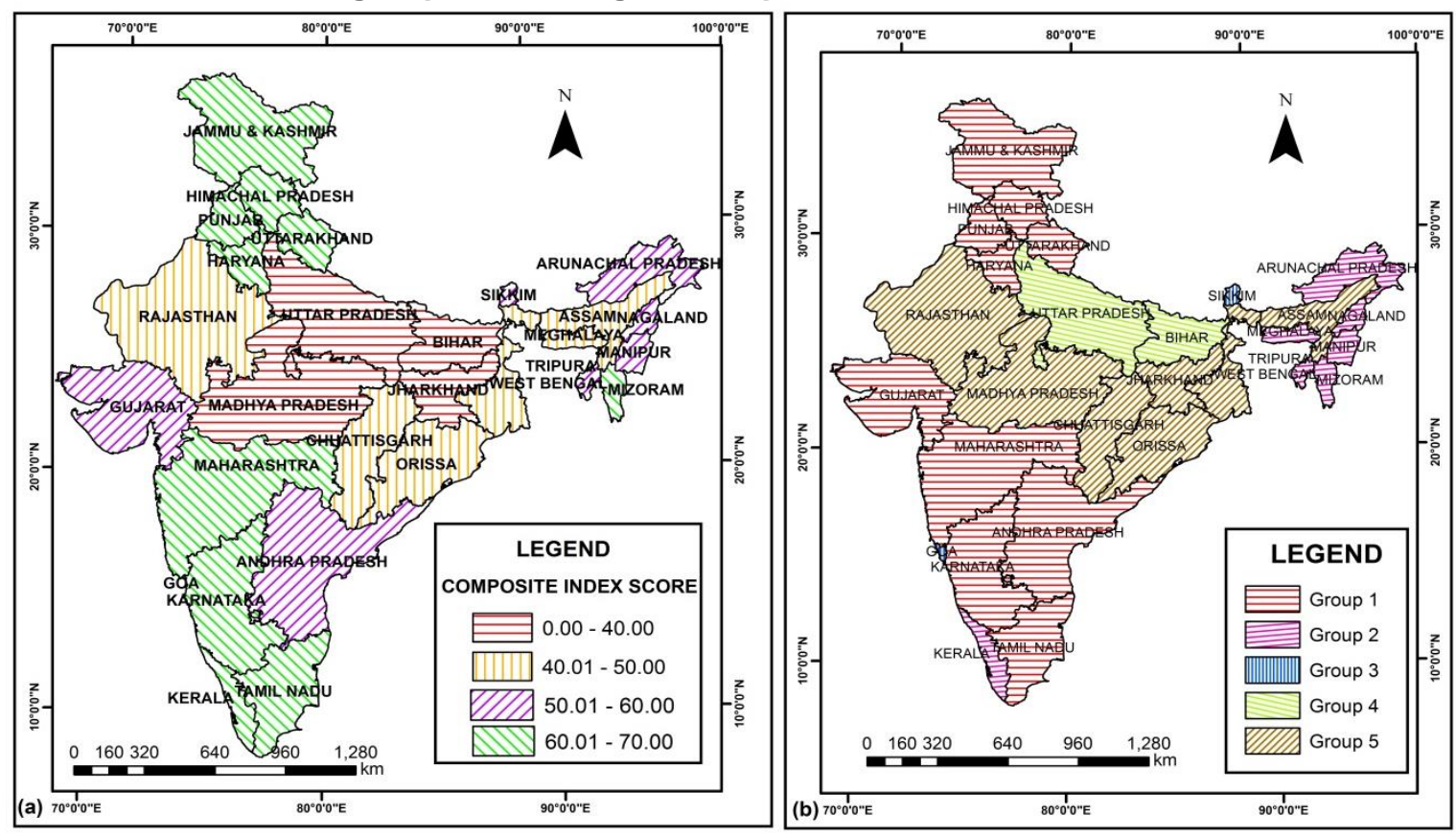

Source: Based on Author's calculation

Therefore, at a subnational level, states belonging to group 3 are superior to all the states with respect to their performance in PSDG Index, while group 2 and 1 have performed satisfactorily and group 4 and 5 have performed the worst and need more government interventions to help progress in achieving sustainability by 2030 .

\section{Issue-specific Hindrances}

The indicators were clustered together according to their level of achievement at India's subnational level. The hierarchical arrangement of the indicators in the dendogram in figure 2 explains which of the primary sustainable development targets need the least, intermediate and most attention in India at sub-national level. Over the years, India has witnessed a remarkable increase in the water sector to provide water not only to its growing population but also for agriculture and irrigation purposes and industrial development. In 2010, the water consumption capacity was approximately 581 trillion litres, where 89 percent was accounted for irrigation purposes, 7 percent for domestic use and 4 percent for industrial development (KPMG, 2010). Although the country is 'water stressed', effective government interventions through successful implementation of policies have helped in keeping the target of providing universal access to 
improved water to its population on track. Although indicators related to energy was absent in MDGs, India has performed better in providing access to electricity at the state level. India's role in enhancing access of rural and urban households to a minimum level of electricity for lighting and their access to safer and more sustainable cooking and heating fuels and stoves are the first challenges India needs to overcome to achieve goal 7 of the 2030 Agenda. In order to enhance energy provisions for the growing population, India has started increasing its renewable energy generation capacity. India's renewable energy installed capacity has grown from 3.9 GW in 2003-14 to about 50 GW in 2016 (Ministry of New and Renewable Energy, 2017). Similarly, wind energy accounts for $28.70 \mathrm{GW}$ or 57.4 percent of the installed capacity followed by Solar power 9.01 GW, small hydro power $4.33 \mathrm{GW}$ and biomass power $7.85 \mathrm{GW}$. CEA also states that India's total potential for power generation from renewable energy resources is estimated at $1198856 \mathrm{MW}$ and Gujarat, Rajasthan, Maharashtra and Andhra Pradesh has the highest potential to utilize their renewable energy generation capacity. India's awareness towards inclusion of renewable energy to achieve sustainable energy development is remarkable through the introduction of the National Solar Missions in 2011 by the Ministry of New and Renewable Energy (Kumar et. al, 2011) and further incorporation of Solar City mission in 2015 also hints at its strive to achieve goal 7 successively by 2030 .

India's access to basic sanitation services is very poor. The Total Sanitation Campaign in 1999 was the first fruitful initiative by the Government to improve rural sanitation conditions in India, which was followed by the Nirmal Bharat Abhiyan in 2012. The rural households with access to toilet facilities have increased by 8.8 percent from 2001 to 2011 (Census of India, 2011) while that of urban areas have increased by 7.7 percent. Rural development programmes need more attention because 69.3 percent of rural households have no access to toilet facilities, which is four times the number of urban households lacking the same (Census of India, 2011). The number of people opting for open defecation was around 600 million by the end of eleventh five year term (Planning Commission, 2013). Currently, Swachh Bharat Abhiyan was introduced in 2014 to achieve target 2 of goal 6 of 2030 Agenda in the rural areas of India. The responsibility of upgrading urban sanitation condition falls under the purview of the Ministry of Urban Development under the Jawaharlal Nehru National Urban Renewal Mission (JNNURM). The mission aims to increase cleanliness levels in the rural areas through Solid and Liquid Waste Management activities and promote Open Defecation Free, clean and sanitised Gram Panchayats (National Sample Survey Office, 2016). India's preparation towards clean, hygienic and universal access to improved sanitation has been initiated and will help in reaching the global goals target by 2030 .

India faces serious challenges on the food security issues of the nation. The contribution of the agriculture sector in the nation's GDP is only 14 percent and during the last two decades, the growth rate of crop production and yield has declined. The global price of food exploded in 2007 and cast a significant impact on the food production and control on the export of food grains in India (Timmer, 2010). India has not only been severely affected by the decline in agricultural production to feeds its population but also India's attempt to decrease the rate of malnutrition among children, adults, especially women is far behind from achievement. The percentage of underweight children below the three years of age have decreased marginally, only by 2.3 percent from 1998-99 to 2005-06 (Boopathy et al., 2014). The proportion of the undernourished population is not on track and there is a need for universal access to safe, nutritious and sufficient food for all available all year round to population of different groups by 2030. To address the problem of India's food security, Government is providing the food grains at cheaper prices through Public Distribution System. To reduce corruption in food distribution governance, digitalization of ration cards have been made mandatory to avail benefits from the Government. In 2001, the National Programme of Mid-Day Meal in Schools was initiated by the Government not only to increase the enrolment rates of children in schools but also to improve 
the nutrition levels among school children (Chutani, 2012). India's struggle to improve health indicators during the era of MDGs was extraordinary but the nation's struggle to achieve the optimum global value of reducing the maternal mortality ratio to 70 per 100,000 live births is yet to be achieved. The low number of maternal mortality ratio reflects lesser inequities in access to health services. Maternal mortality ratios are high in regions with poor health care facilities and are less likely to be attended by skilled personnel (Ronsmans, Graham, \& group, 2006).

Figure 02: Dendogram Showing the Hierarchical Arrangement of the Three Groups of Indicators according to their Level of Achievement from Best to Worst at A Sub-National Level

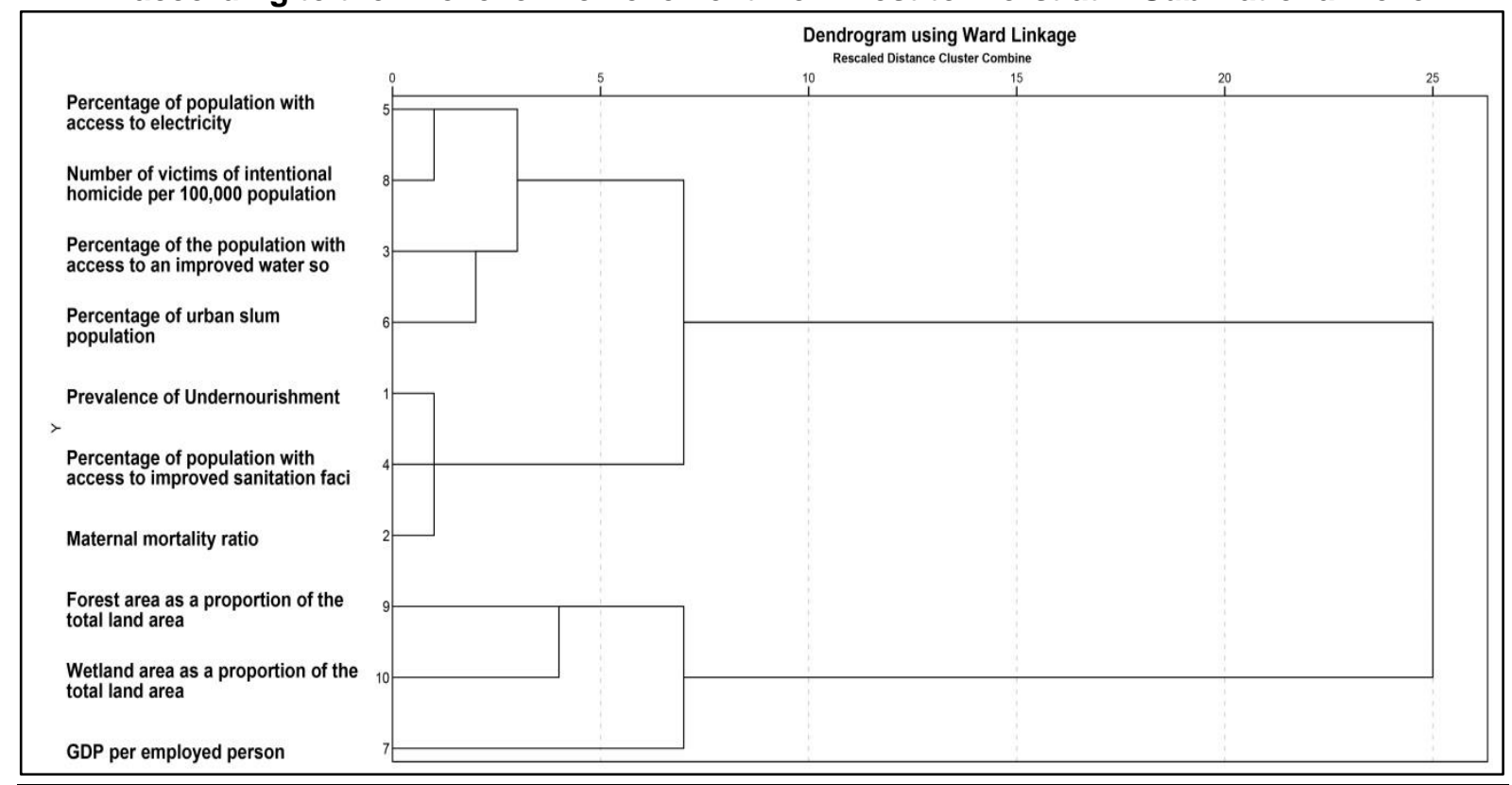

Source: Author's calculation

The neoliberal economic policies of India have led to the remarkable economic growth of the country since 1991 (Ahluwalia, 2002; Kapila, 2010) but the labour productivity seems to be poor and stagnant for India. Often progress in labour productivity does not guarantee decent work for all, but improvements in working conditions and growth in employment opportunities are accompanied by high levels of labour productivity. India has numerous urban and rural schemes to facilitate employment opportunities for the working population. To encourage the overall economic growth of the nation, India should consider poverty alleviation programmes and vocational training of unskilled labourers who are involved in primary economic sectors (Loayza \& Raddatz, 2010). Another important aspect of improving quality of life includes freedom from violence. Intentional homicide in India is mainly a function of gender based crime and caste based communal conflicts and the incidents are greater in districts with lower sex ratios; but with the passage of time there has been a significant decline in the total number of homicides from 2000 to 2010 and simultaneously use of guns for killing has also decreased (Marwah, 2014). Climate change, environmental conservation, and rejuvenation are an integral part of the 2030 agenda. Despite facing key challenges of rapid urbanization and industrialization, India in the last few decades has implemented policies to control pollution and maintain ecological balance. Ministry of Environment, Forests and Climate Change has introduced the National Afforestation Programme in 2016 to promote afforestation, tree plantation and eco-restoration of degraded forests. Simultaneously centrally sponsored schemes of National River Conservation Plan and National Plan for Conservation of Aquatic Ecosystems in $\mathbf{2 0 1 5}$ for the conservation of rivers, lakes and wetlands in the country has also been introduced by the Ministry. If India can successfully implement the schemes to conserve its natural resources, then achieving goal 15 will be easier by 2030 . 


\section{Conclusion}

In this study, the present status of India's primary SDGs is analyzed with the help of a composite index. A cluster analysis was performed to examine the region-specific and issuespecific problems of sustainable development in India. The study highlights that India has to overcome numerous hurdles to achieve the universal targets of sustainable development by 2030. At the sub-national level, 14 out of 29 states have performed well in the PSDG index, while the other states need to focus on developing the quality of life of their people and provide infrastructure services and utilities to both their rural and urban population. The PSDG Index throws light upon the basic goals of sustainability that a country needs to achieve by 2030 and assessing its progress prior to 2015 recognizes the direction in which government interventions and policies are most required. The study adds support to the existing literature on issuespecific problems affecting India at a sub-national level. India needs to protect and restore terrestrial and inland freshwater ecosystems, especially forests, mountains, wetlands and dry lands. The rate of employment growth about economic growth has suffered stagnation at various time periods from 2000 to 2015 (Papola, 2013), and therefore a positive shift in this sector is required to help India achieve inclusive and productive economic growth in the coming years. Financial incentives related to water, sanitation and improvements in health sector have already been initiated by the Government through Jal Jeevan Mission, Swachh Bharat Mission and Jan Arogya Yojana. With the help of National Skill Development Agency, employment focusing on infrastructure projects and skill development projects will be implemented. Thus, India may seem distant in achieving sustainable development by 2030 , but effective policy implementation, capacity building and financial assistance (Bhamra, Shankar, \& Niazi, 2015) will help India fulfil these ambitious SDGs by 2030.

\section{Reference}

1. Ahluwalia, M. S. (2002). Economic reforms in India since 1991: Has gradualism worked? Journal of Economic Perspectives, 16(3), 67-88.

2. Bhamra, A., Shankar, H., \& Niazi, Z. (2015). Achieving the Sustainable Development Goals in India A Study of Financial Requirements and Gaps. New Delhi.

3. Boopathy, G. M., Maitra, S., Bhaskar, S., Pratap, R., Shanti, R., \& Hansraj. (2014). Millennium Development Goals India Country Report 2014. Social Statistics Division Ministry of Statistics and Program Implementation, Government of India.

4. Chaudhuri, S., \& Roy, M. (2017). Rural-urban spatial inequality in water and sanitation facilities in India: A cross-sectional study from household to national level. Applied Geography, 85, 27-38.

5. Chutani, A. M. (2012). School lunch program in India: Background, objectives and components. Asia Pacific Journal of Clinical Nutrition, 21(1), 151-154.

6. FAO, I. (2016). WFP (2015), The State of Food Insecurity in the World 2015. Meeting the 2015 international hunger targets: taking stock of uneven progress. Food and Agriculture Organization Publications, Rome.

7. Fraley, C., \& Raftery, A. E. (1998). How many clusters? Which clustering method? Answers via model-based cluster analysis. The Computer Journal, 41(8), 578-588.

8. Fukuda-Parr, S. (2004). Millennium Development Goals: why they matter. Global Governance, 10(4), 395-402.

9. Gurjar, B. R., Ravindra, K., \& Nagpure, A. S. (2016). Air pollution trends over Indian megacities and their local-to-global implications. Atmospheric Environment, 142, 475-495.

10. Guttikunda, S. K., Goel, R., \& Pant, P. (2014). Nature of air pollution, emission sources, and management in the Indian cities. Atmospheric Environment, 95, 501-510.

11. Hirschberg, J. G., Maasoumi, E., \& Slottje, D. J. (1991). Cluster analysis for measuring welfare and quality of life across countries. Journal of Econometrics, 50(1-2), 131-150.

12. Kapila, K. (2010). The terms of trade. The State in India After Liberalization: Interdisciplinary Perspectives, 197.

13. KPMG. (2010). Water sector in India: Critical Issues in India: Overview and focus areas fot the future, (September), 24. Retrieved from https://www.kpmg.de/docs Water_sector_in_India.pdf

14. Kumar, A., Kumar, K., Kaushik, N., Sharma, S., \& Mishra, S. (2011). Renewable energy in India: current status and future potentials. Renewable and Sustainable Energy Reviews, 14(8), 2434-2442.

15. Kwatra, S., Kumar, A., Sharma, P., Sharma, S., \& Singhal, S. (2016). Benchmarking sustainability using indicators: An Indian case study. Ecological Indicators, 61, 928-940.

16. Kwon, Y., Lee, H., \& Lee, H. (2018). Implication of the cluster analysis using greenhouse gas 
emissions of Asian countries to climate change mitigation. Mitigation and Adaptation Strategies for Global Change, 1-25.

17. Leal Filho, W., Azeiteiro, U., Alves, F., Pace, P., Mifsud, M., Brandli, L., ... Disterheft, A. (2018). Reinvigorating the sustainable development research agenda: the role of the sustainable development goals (SDG). International Journal of Sustainable Development \& World Ecology, 25(2), $131-142$.

18. Loayza, N. V, \& Raddatz, C. (2010). The composition of growth matters for poverty alleviation. Journal of Development Economics, 93(1), 137-151.

19. Mahanta, C. (2010). India's north east and hydropower development: Future security challenges. South Asian Survey, 17(1), 131-146.

20. Marwah, S. (2014). Mapping murder: Homicide patterns and trends in India. Journal of South Asian Studies, 2(2), 145-163.

21. Milligan, G. W., \& Cooper, M. C. (1988). A study of standardization of variables in cluster analysis. Journal of Classification, 5(2), 181-204.

22. Ministry of Drinking Water and Sanitation. (2013). Annual Report 2012-2013. Retrieved from https://mdws.gov.in/sites/default/files/AnualReport12_13_Eng.pdf

23. Ministry of Drinking Water and Sanitation. (2014). Annual Report 2013-2014. Retrieved fromhttps://mdws.gov.in/sites/default/files/Drinking_Water_Annual_Report_2013_14_English.pdf

24. Ministry of New and Renewable Energy. (2017). Power from renewables - grid interactive and off-grid renewable power. Annual Report. Retrieved from http://mnre.gov.in/file-manager/annual-report/20162017/EN/pdf/3.pdf]

25. Mukherjee, S., \& Chakraborty, D. (2014). Three decades of human development across Indian states: Inclusive growth or perpetual disparity?

26. National Sample Survey Office, M. of S. and P. I. (2016). Swachhta Status Report.

27. Omorou, A. Y., Coste, J., Escalon, H., \& Vuillemin, A. (2016). Patterns of physical activity and sedentary behaviour in the general population in France: cluster analysis with personal and socioeconomic correlates. Journal of Public Health, 38(3), 483-492.

28. Panda, B. K., \& Mohanty, S. K. (2018). Progress and prospects of health-related sustainable development goals in india. Journal of Biosocial Science, 1-18.

29. Papola, T. S. (2013). EMPLOYMENT GROWTH DURING THE POST-REFORM PERIOD. Indian Journal of Labour Economics, 56(1).

30. Planning Commission. (2013). Twelfth Five Year Plan (2012-2017) Economic Sectors: Volume II.

31. Planning Commission, G. of I. (2014). Report of the expert group to review the methodology for measurement of poverty. https://doi.org/June 2014

32. Pradhan, P., Costa, L., Rybski, D., Lucht, W., \& Kropp, J. P. (2017). A systematic study of sustainable development goal (SDG) interactions. Earth's Future, 5(11), 1169-1179.

33. Rao, S. (2015). Disparities in infrastructure as a barrier to attain faster inclusive growth trajectory: an inter-state analysis. Indian Journal of Economics and Development, 11(3), 725-741.

34. Reserve Bank of India. (2018). HANDBOOK OF STATISTICS ON INDIAN STATES.

35. Ronsmans, C., Graham, W. J., \& group, L. M. S. S. steering. (2006). Maternal mortality: who, when, where, and why. The Lancet, 368(9542), 1189-1200.

36. Roy, P. S., Roy, A., Joshi, P. K., Kale, M. P., Srivastava, V. K., Srivastava, S. K., .. Meiyappan, P. (2015). Development of decadal (1985-1995-2005) land use and land cover database for India. Remote Sensing, 7(3), 2401-2430.

37. Sachs, J., Schmidt-Traub, G., Kroll, C., Durand-Delacre, D., \& Teksoz, K. (2016). SDG Index \& Dashboards, A Global Report. Sustainable Development Solutions Network. https://doi.org/10.1016/S0140-6736(09)61513-0

38. Saint-Arnaud, S., \& Bernard, P. (2003). Convergence or resilience? A hierarchical cluster analysis of the welfare regimes in advanced countries. Current Sociology, 51(5), 499-527.

39. Sarstedt, M., \& Mooi, E. (2014). Cluster analysis. In A concise guide to market research (pp. 273324). Springer.

40. Spaiser, V., Ranganathan, S., Swain, R. B., \& Sumpter, D. J. T. (2017). The sustainable development oxymoron: quantifying and modelling the incompatibility of sustainable development goals. International Journal of Sustainable Development \& World Ecology, 24(6), 457-470.

41. Sulkowski, A., \& White, D. S. (2016). A happiness Kuznets curve? Using model-based cluster analysis to group countries based on happiness, development, income, and carbon emissions. Environment, Development and Sustainability, 18(4), 1095-1111.

42. Timmer, C. P. (2010). Reflections on food crises past. Food Policy, 35(1), 1-11.

43. United Nations. (2016). Transforming our world: The 2030 agenda for sustainable development.

44. Vani, S. V. S., Bhaumik, S., Nandan, A., \& Siddiqui, N. A. (2017). Hazardous Waste-Impact on health and Environment for sustainable development in India. World Scientific News, 70(2), 158-172. 